\title{
S-1. 視覚ディスプレイと照明技術
}

\author{
岡 林繁 \\ (名 城 大 学)
}

\section{1.はじめに}

照明学会がかバーする技術領域に, 視覚心理や, 視環境, 視覚情報などに関連する計測評価技術が ある. 近年の高度情報化のトレドとディスプレ任バ゙イ伎術の進歩は，評価技術にも変化をもたらしてい る. 多色表示像の視認性, 照明光下のパ 祄型表示装置の視認性, コヒーレンシーの高い表示光と視認性, ITS などに代表されるドラ仈と表示情報の動的な視認性評価など, 輝度や照度, 色度などの要素だけでは 評価しにくい.これらは照明技術と他の学問領域との境界領域である場合もあるし, 新デバイスの登場 による新しい観点の考察が望まれる場合もある。本報告では,「視覚デイスプレイと照明・視環境ジポジ 姢の入口として,上述した計測技術領域での問題点といくつかの具体的な事例をもとに新たな評価 視点の必要性について述べたい.

\section{2.視觉ディスプレイ照明技術に関わる新しい視点}

(1)パネル型多色表示装置 ナビゲーション表示などに応用されているパ视型多色表示装置は, 使用条件の 制約から, 低コンラス卜条件での視認性確保が重要な課題である.多色表示装置を実際の運転条件で 観察すると,多くのドライバが「赤色表示像は緑色表示像よりよく見える」 ${ }^{(1)}$ と報告する.赤 (R) 緑 (G) 青 (B)のそれぞれの表示色について, 短時間視標呈示実験により表示輝度と認識正答率の関 係を評価すると, 同じ認識正答率を得るには，赤色表示像の輝度が最も低くて良い。一見比視感 度と矛盾するように見える. 被験者が知覚できるぎりぎりの空間周波数閥値を色相ごとに計測 する ${ }^{(2)}$ と, 閾值は赤色が最も高く, 緑色, 青色の順に低下し, 輝度值と認識正答率の関係と整合す る.多色表示装置の表示像の視認性評価では, 輝度データは空間周波数の低周波領域の特性を, 微 細像の認知では高周波領域の特性がドミナントであることが示唆される.

(2)自動車用ヘ师アップディスプレイヘッドアップデイスプレイは表示像を光学虚像として表示するシス公である。 自動車に応用した場合, 表示像の背景となる車外前景と表示像の視距離が異なる場合, 同一視 距離の条件に比較して, 視認に必要なコントラス卜は変化する.視距離の異なる表示像の場合の視認性 は輝度やコントストだけではなく accommodation が何らかの影響を与えていることが示唆される.

(3)表示装置のューザの拡大 加齢に伴う眼光学系透光体の混濁者などが, 種々の表示装置に接する機 会が増加している.白黒表示の場合,一般的には「白黒反転表示」(衴型表示)が中程度以上の白 内障には適していると言われているが, 視認性を向上するため表示文字を太くし, 文字と背景の 面積比率を変化させると, 初”型ポジ型の視認性は反転し新しい評価指標が必要となる.

(4)動画デイスプレイ 仮現運動を利用した動画表示では, 聴覚等の感覚情報が運動視に影響を与えるこ とが報告されている.交通標識における動画表示や,が价ラ仆設計など照明技術で扱うと思われ る社会价ラについても新しい視点の評価尺度が必要とされよう。.

(5)その他 青色発光 LED 等の新しいデイスプレ隹バイスの照明への応用や, 加齢を考慮した表示装置評 価, 表示面の大型化に伴う評価の新しい視点などは, 本シンポジウムで詳細に述べられ討議される.

\section{3.まとめ}

照明技術を単に「照らす技術」と捉えず, 照らして何かを知覚·認知する技術を考えるとき,視覚ディ スプレ関連評価は, 輝度や輝度対比, 色度などで規定される計測技術だけで評価することが困難とな ってきている. 照明学会がこれらの技術領域を包含し, 研究を先導し広く研究者を集結できる求心力 となることを願いたい.

\section{参考文献}

（1）岡林他: 自動車用多色表示装置における色相と輝度が情報受容へ与える影響, 名城総研報, 6, pp199-203(2000)

（2）舟川正美：可読性に影響を与える空間要因に関する研究, 照学誌, 84(11), 793-798(2000) 